\title{
Between Fluxus and the Situationist International:
}

\author{
Gerz's Postsachen
} Roger Rothman

Why "Dada Futures," rather than "Dada's Future"? What to make of the migration of the "s" from the end of "Dada" to the end of "Future"? Can it be said that Dada has a future at all, much less multiple futures? Implicit in the conference's pluralization of the word "future" is the challenge to conceive of Dada's legacy as multiple, and perhaps even contradictory. Doing so asks us to read Tzara's 1918 insistence on Dada's "great negative work of destruction" (41) as having unleashed a multitude of perhaps incompatible reverberations. This essay is an examination - in miniature - of the plural, indeed contradictory, future of Dada. Two of its principal "futures" - Fluxus and the Situationist International - can legitimately claim to be Dada's rightful heir, but the lessons they learned from Tzara and company are in fundamental respects diametrically opposed. In an effort to elaborate these two distinct "futures" and set them in productive dialog with each other, this essay will make use of an object (more precisely a collection of objects) housed in the Special Collections of the University of Iowa Libraries, and available online as part of its Fluxus Digital Collection (itself one of the "futures" of dadaism, as it serves to extend the university's International Dada Archive).

Jochen Gerz's Postsachen ("Postal Items," or simply "Mail") is a collection of roughly twenty printed works that Gerz completed between 1968 and 1972 (fig. 1; fig. 2). While some of the works were expressly designed to be sent through the mail ("Rechtsschebibung," for example, is in fact a postcard, with the title words printed in large letters on the front and empty spaces on the back for the sender to write a note, append an address, and add a stamp), most of the items were originally constructed for other purposes (such as a two-page statement, entitled "Pour un langage du fair," which had been written for a symposium on contemporary poetic practices). Postsachen was published by Hundertmark editions, a press that began in 1970 with a focus on German and Austrian artists (including, for example, Joseph Beuys, Arnulf Rainer, and Hermann Nitsch) as well as an array of artists associated with Fluxus (such as Ken Friedman, Eric Andersen, Ben Vautier, Ben Patterson, and Philip Corner). Like Postsachen, which 
was published in an edition of twenty-seven, most Hundertmark boxes were printed in editions of under one hundred, with some as few as five or ten. ${ }^{1}$

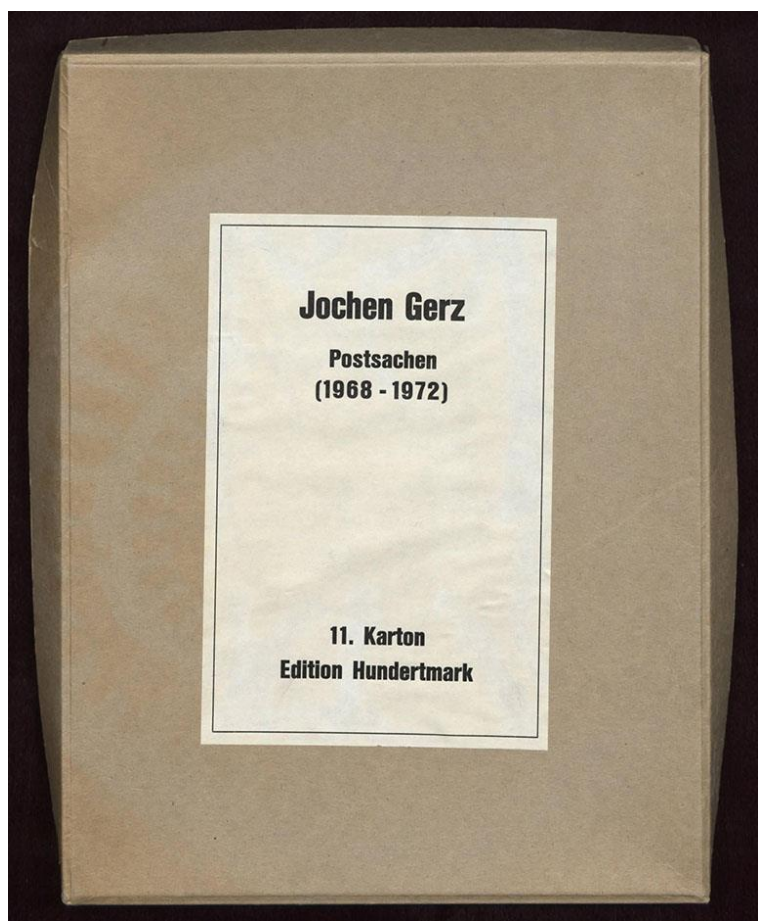

Figure 1: Joachim Gerz, Postsachen (1968-1972) (box closed) (Edition Hundertmark, 1973). Fluxus West Collection, Special Collections, University of Iowa Libraries. (C) 2020 Artists Rights Society (ARS), New York / VG Bild-Kunst, Bonn.

Though Postsachen collects Gerz's work from the early part of his career (19681972), when the artist was associated with conceptual and performance practices, today Gerz is better known for the public art projects he began developing in the 1980s (and into the present), ${ }^{2}$ the most influential of which, Monument Against

\footnotetext{
${ }^{1}$ For details of Hundertmark editions, which has continued into the twenty-first century, see their website: http://www.hundertmark-gallery.com/editions.0.html.

2 Jonathan Vickery offers a concise account of Gerz's general reception: “Jochen Gerz (born Berlin 1940) was for most of the 1960s and 1970s a conceptual artist, also known for his innovative work in performance and multimedia. He shared the German pavilion with Joseph Beuys at the Venice Biennale in 1976, but since 1984 he has concentrated on installations and public art projects" (Vickery 234, note 6). For Gerz's early poetic work, see Vowickel (40).
} 
Fascism, was produced in collaboration with his wife, Esther Shalev-Gerz. ${ }^{3}$ In 1986, a lead-clad column, twelve meters tall, was installed in the Hamburg city center.

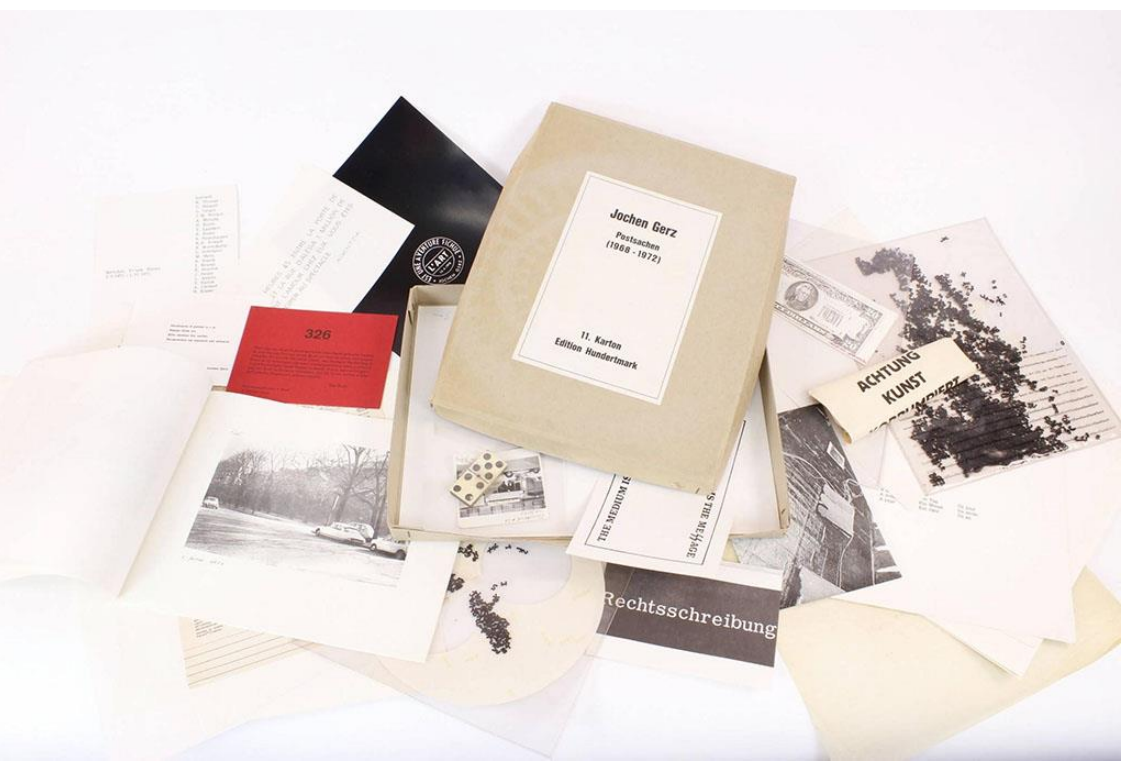

Figure 2: Joachim Gerz, Postsachen (1968-1972) (box open) (Edition Hundertmark, 1973). Fluxus West Collection, Special Collections, University of Iowa Libraries. (c) 2020 Artists Rights Society (ARS), New York / VG Bild-Kunst, Bonn.

Members of the public were invited to leave their marks on its initially empty surface. Gradually the column was lowered so that the upper portions could be marked as well. Ultimately, all that remained visible was a lead square on the ground with an identifying plaque, the marks of the public buried indefinitely beneath the city street. Gerz refers to this work, and those that followed, as engaged in an art of "public authorship," which he describes as "a system that involves the artist, the commissioner, and the public equally in forming the work"

\footnotetext{
${ }^{3}$ Scholarship on Gerz's public works has tended to focus on issues of historical memory, monumentalisation, and the bourgeois public sphere. Particularly influential has been the work of Andreas Huyssen on historical memory and James Young on the "countermonument." For example, Giuseppe Di Liberti recently described Gerz's public projects as "monument-événement" ("event-monuments") (18). Thomas Stubblefield is one of few historians to have been critical of Gerz's public works, arguing that "[i]n the end, the disappearance of the monument [Monument Against Fascism] would function as a projection of an already remembered past that actively repressed the creative aspects of memory as much as it reinforced existing narratives of history" (2). With the recent "participatory turn," Gerz's work is being rethought in relation to artists like Hans Haacke, Andrea Fraser, and Tania Bruguera (Frieling 166-69).
} 
("Toward Public Authorship" 652). For Gerz, the move from private to public authorship is an extension of the avant-gardist call for the sublation of art into life in that it proposes to fuse "culture" and "city":

The border between the private and the public must collapse if we do not want to find ourselves in a continental, a national or a city prison of privilege. The cultural city is a child of democracy. We have to share the intelligent tools with which we know how to create and build amongst ourselves. We have to teach that part of us which builds to make cultural use of what we do.... The cultural [city] has to leave behind the hidden private sphere of the creativity of the few which it has become in postindustrial societies, 'the theatre of secrecy' (or the terror of intimacy, as Richard Sennett puts it). The issue of the cultural city concerns what is the priority, where do the energy and the money go? The decision is taken: the priority is public debate on issues and as an issue, on memories and as a memory, on and as information - public debate creating intelligence and authorship, and a sense of shared responsibility rather than unshared privilege. ("Creating a Cultural City" 462)

Though the texts and small objects collected in Postsachen predate both the term "public authorship" and the artist's developed theorization of it, one of them - a roll of medium-sized stickers with the phrase "Achtung Kunst Korrumpiert" in all caps - is arguably its prototype (fig. 3). It is also Gerz's most cited early work. Initially presented in its Italian-language version, Attenzione L'arte corrompe was pasted in several locations throughout the city of Florence in 1968, including, most provocatively, on the pedestal of Michelangelo's David. The following year, the German-language version was pasted on various sites in Basel. Versions of the sticker have also appeared in English: "Caution Art Corrupts" (Hohlfeldt 9).

By virtue of its explicit identification of art with destruction, Caution Art Corrupts is self-evidently indebted to Dada, and thus constitutes one of its multiple futures. At the same time, by virtue of its equally explicit insistence upon expansion of art beyond the walls of the gallery and museum, Caution Art Corrupts is no less indebted to two of Dada's most significant post-war manifestations: Fluxus and the Situationist International (SI). Indeed, what is most fascinating about this work - and indeed of all the texts and objects collected in Postsachen is that it navigates these two post-dadaist formations with unparalleled complexity.

Gerz has acknowledged both Fluxus and SI as formative precursors. Regarding the challenges posed by public authorship, Gerz has offered the following:

Art is not the most difficult thing one can do or put up with today. More difficult, however is to 'divert' art (as the situationists put it), using its aura in order to make something more surprising happen: public meaning. In this way, art becomes an art of dialogue as form; a form that takes on 
a life of its own. And this I would call 'poetry' today. ("Toward Public Authorship" 652)

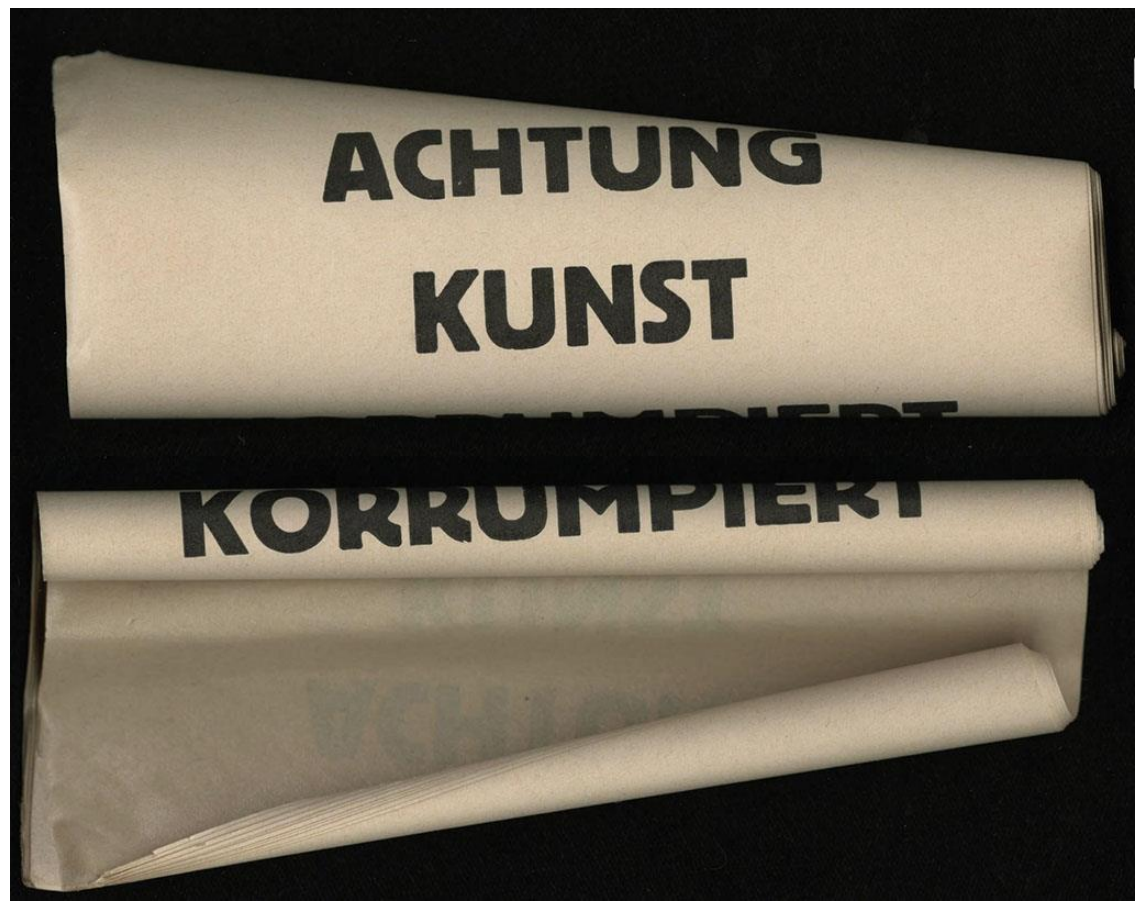

Figure 3: Joachim Gerz, "Achtung Kunst Korrumpiert." Postsachen. Fluxus West Collection, Special Collections, University of Iowa Libraries. (c) 2020 Artists Rights Society (ARS), New York / VG Bild-Kunst, Bonn.

Though the Situationists would reject the claim that the properly détourned text manifests as "poetry" - Debord spoke rather of "educative propaganda" (Debord and Wolman) - Gerz's description of his manipulation of found texts and images are indisputably indebted to the Situationist practice of détournement and its critical imperative. ${ }^{4}$ Evidence of Gerz's engagement with Situationist conceptions of

4 "Every reasonably aware person of our time is aware of the obvious fact that art can no longer be justified as a superior activity, or even as a compensatory activity to which one might honorably devote oneself. . . In the civil-war phase we are engaged in, and in close connection with the orientation we are discovering for certain superior activities to come [certaines activités supérieures à venir], we believe that all known means of expression are going to converge in a general movement of propaganda [un mouvement général de propagande] that must encompass all the perpetually interacting aspects of social reality. There are several conflicting opinions about the forms and even the very nature of educative 
public art as a negative dialectic is especially evident in his description of a paired project in Coventry, UK (1999-2004). To commemorate the devastation caused by the German bombings of Coventry during World War II, Gerz posed the following questions to the citizens of the city: "Who are the enemies of the past?" and "Who are your modern friends?" The responses were used in the development of a laminated glass obelisk, roughly four and half meters high, and eight glass plaques with engraved inscriptions. Reflecting on his vision for the work, Gerz describes it as kind of détourned monument, or monumental détournement:

[A]s products of public authorship, The Public Bench and The Future Monument [1999-2004] take a critical stance both content-wise and in terms of their form. In making reference to unresolved historical tensions, or even traumatic memories. . . . The Future Monument problematises historical memory by admixing names of former colonies, and references to the present ethnic heterogeneity of 'the British.' ("Toward Public Authorship" 654)

Like Debord, for whom the détourned image functions as a tool of revelatory insight, ${ }^{5}$ Gerz's works of public authorship are constructed, so he insists, to heighten, rather than resolve contradictions. ${ }^{6}$

At the same time, however, Gerz has aligned other aspects of his practice with the decidedly utopian affirmation of everyday life as articulated by John Cage and the Fluxus artists who followed in his footsteps. In an interview from 2001, Gerz expressed a certain reluctance to abide Situationism's critique of spectacle as

propaganda, opinions that generally reflect one or another currently fashionable variety of reformist politics. Suffice it to say that in our view the premises for revolution, on the cultural as well as the strictly political level, are not only ripe, they have begun to rot" (Debord and Wolman 14).

5 Debord's definition of détournement reads as follows: "Détournement: Short for 'détournement of preexisting aesthetic elements.' The integration of present or past artistic productions into a superior construction of a milieu. In this sense there can be no situationist painting or music, but only a situationist use of those means. In a more elementary sense, détournement within the old cultural spheres is a method of propaganda [une méthode de propagande], a method which reveals the wearing out and loss of importance of those spheres [qui témoigne de l'usure et de la perte d'importance de ces sphères]" ("Definitions"; "Définitions" 13).

${ }^{6}$ Doris von Drathen identifies Gerz's dialectical practice as Adornian, rather than Debordian: "Jochen Gerz ... has avoided sublimating life in favor of actually confronting life itself. His solution was not to harmonize contradictions, but rather to heighten them." And: "No harmony, no reconciliation. Gerz doesn't smooth over the contradictions, the doubts; he shapes the divergent, lets multiplicity, with all its singularities and fragments, its hesitation, form pictures that are not pictures. They become a language that says something in secret, that denounces what it does not say" $(142,146)$. For an incisive comparative analysis of Adornian and Debordian dialectics, see Jappe. 
productive in the present. In response to Simon Baker's question, "Given the changes in the way that installation is perceived, do you still think that it can be a resistant practice?" Gerz replied: "I think that even terms like 'resistance' are very relative and have now become part of the commemorative process. We commemorate resistance and we commemorate progress and I don't think that every evocation of 'resistance' means what it says" (Gerz and Baker 28). For this reason, Gerz is not nearly as hostile to museums as were the Situationists, even while reconceiving the boundaries of the museum:

A museum can help an installation to happen at the corner of a street where there is no museum and no curators and no invitation cards. But the museum is still backing it theoretically, spiritually, and socially by saying this is what our work is about and we are backing this. It is interesting that in this way you could have something happening in society that is not the work of an artist, perhaps in a 'fluxus' or a 'dada' way. ... The museum is like a tiny society or an image of society and installation is a laboratory for the functioning of society. . . . So I think that bringing the idea of installation into society brings the museum into society, which is a utopian idea which has never left us. (Gerz and Baker 29)

Before going any further in our investigation of Gerz's entanglements with both Fluxus and the SI, it is crucial to point out that, despite their proximity (both geographically and temporally), the artists involved in these two collectives had no substantive interactions and seemed to have had little interest in each other's activities. ${ }^{7}$ Similarly, scholars have shown little interest in comprehending the two movements in any coordinated fashion. ${ }^{8}$ Why has so little work been done to assess the connections between Fluxus and the SI and why is it that so few artists - with the notable exception of Gerz - have sought to practice in the space between them? I would like to argue that the difficulty in reconciling the two is marked by the very terms Gerz uses when he speaks of each: "critical" in the case of the SI, "utopian" in the case of Fluxus. And this, I would argue, is what Postsachen stages for us with unique clarity: the conflict between the Situationist vision of the avant-garde as a critical project and the Fluxus vision of the avantgarde as an affirmative endeavor. Gerz himself was not a member of either Fluxus or the SI, but at first glance at least, it seems that in his early years, he was struggling to work through these two competing visions of Dada's future, if not to reconcile them, at least to set them in dialogue.

\footnotetext{
7 "There is little relation between Fluxus and Situationism other than a vague temporal overlap at some moments in the 20th century. Many people in Fluxus probably knew something about the Situationists, but no one seemed to care. I don't recall anyone ever talking about them. There was no dialogue" (Friedman).

${ }^{8}$ Stewart Home is the most notable exception.
} 
In proposing to understand Fluxus as an art of utopian affirmation, I do not mean to suggest that it was in all respects opposed to the project of negation and critique. Indeed, early on, Maciunas sought to defend Fluxus as an extension of dadaist critique, most unequivocally in the manifesto-like statement Maciunas distributed at the Festum Fluxorum in Düsseldorf in February 1963. There he railed against "bourgeois sickness," and called for a "flood and tide in art," to be led by a cadre of "cultural, social and political revolutionaries" (Maciunas; Smith, "Developing a Fluxable Forum" 4). ${ }^{9}$

The affirmative dimension of Fluxus stems less from Maciunas's endeavors (the early ones at any rate) and more from the influence of John Cage, whose 1959 class on composition was crucial to the emergence of both Fluxus and Happenings (Smith, Fluxus 23-31). This affirmative dimension stems from Cage's notion which can be traced back to Dada, but which requires a different route than the one traversed by Debord and the Situationists - that the art should be "an affirmation of life - not an attempt to bring order out of chaos nor to suggest improvements on creation, but simply a way of waking up to the very life we're living which is so excellent once one gets one's mind and one's desires out of its way and lets it act of its own accord" (Silence 12). Similarly, in an interview that took place in 1978, Cage, said the following about his engagement with the political activism of the sixties: "I wasn't interested in critical or negative action. I'm not interested in objecting to things that are wrong. I'm interested in doing something that seems to be useful to do. I don't think critical action is sufficient" (Kostelanetz 282).

${ }_{9}$ Coincidentally, 1963 was the same year in which the Situationists mounted their only official art exhibition, which included a collection of détourned paintings Debord called "Directives." Organized by J. V. Martin, Michèle Bernstein, Guy Debord, and Jan Strijboch, the exhibition, "Destruction of the RSG-6," took place at Galerie EXI in Odense, Denmark. In place of paintings, the walls were littered with signs announcing characteristically situationist imperatives such as "Dépassement de l'art" and "Réalisation de la philosophie"). Of the event, Debord wrote: "For this 'RSG-6' event we have recreated the atmosphere of an atomic fallout shelter. After passing through this thought-provoking ambience, the visitor enters a zone evoking the direct negation of this type of necessity. The medium here used in a critical fashion is painting" ("The Situationists and the New Forms of Action" 406). In Internationale Situationniste no. 9, the exhibition was described as follows: "In June 1963 the SI organized a 'Destruction of RSG-6' demonstration in Denmark, under the direction of J. V. Martin. On this occasion the situationists distributed a clandestine reissue of the English tract Danger: Official Secret - RSG 6, signed 'Spies for Peace,' which revealed the plan and function of 'Regional Seat of Government \#6.' A theoretical text, The Situationists and the New Forms of Action in Politics and Art, was also issued in Danish, English and French. In one area an ugly reconstruction of a bomb shelter was set up; in another were exhibited Martin's 'Thermonuclear Maps' (détournements of Pop Art representing various regions of the globe during World War III)." (Debord, "The Situationists and the New Forms of Action" 490 (translator's note 405)). 
What is so fascinating and provocative about Cage's "affirmation of life" is that it stands diametrically opposed to everything we have come to understand as crucial about the avant-garde. As the Frankfurt school has taught us well, there is nothing more irredeemable than that which is "affirmative." As Herbert Marcuse defined it:

[A]ffirmative culture is . . that culture of the bourgeois epoch which led in the course of its own development to the segregation from civilization of the mental and spiritual world as an independent realm of value that is also considered superior to civilization. Its decisive characteristic is the assertion of a universally obligatory, eternally better and more valuable world that must be unconditionally affirmed: a world essentially different from the factual world of the daily struggle for existence, yet realizable by every individual for himself "from within," without any transformation of the state of fact. (Marcuse, Negations 95)

What distinguished Cage's affirmative practice from the mass cultural phenomena Marcuse lamented is the insistence, in Cage's case, that the act of affirmation remain rooted in the mundane, in what Marcuse called "the daily struggle for existence," and that it assiduously avoid the sort of dualism that constructs an ideal world on top of the real, an "independent realm" distinct from the immanent world of everyday life. The politics of affirmation of the sort Cage endorses is a politics of the small, a politics in which the better world of tomorrow is found in the interstices of the present. The task of the those who abide affirmation is thus not to "sweep and clean" as Tristan Tzara proposed in his 1918 Dada Manifesto, but rather to slowly and carefully build up from the ground on which it stands, regardless of how small and bare that ground may be.

This, for example, is the essential lesson of Yoko Ono's Ceiling Painting of 1966. A ladder stands in the middle of the gallery space, and a painting, hung from the ceiling above, beckons the viewer to climb up to read the print that is too small to discern from the ground. Once ascended, the viewer must take hold of the magnifying glass that hangs from a wire. Only then is it possible to read the word "YES."

It is easy to mock such works as sentimental and simple-minded. And no doubt that was the position taken by Debord in his critique of Kaprow's happenings. In his essay, "The Avant-Garde of Presence," Debord took aim at the Happenings of Kaprow, Dine, Oldenburg, and others. Though he did not mention Fluxus, his criticism would apply to it as well:

The happening is a sort of spectacle pushed to the extreme state of dissolution, a vaguely dadaist-style improvisation of gestures performed by a gathering of people within a confined space. . . In its naïve striving to "make something happen," its absence of separate spectators and its desire to liven up (however feebly) the impoverished range of present human relations, the happening can even be considered as an attempt to 
construct a situation in isolation, on a foundation of poverty (material poverty, the poverty of encounters, the poverty inherited from the artistic spectacle, and the poverty of the "philosophy" that has to considerably "ideologize" the reality of these events). In contrast, the situations defined by the SI can be constructed only on a foundation of material and spiritual richness. This amounts to saying that the first ventures in constructing situations must be the work/play of the revolutionary avantgarde; people who are resigned in one way or another to political passivity, to metaphysical despair, or even to being subjected to an art of total noncreativity, are incapable of participating in them. (143)

Herein lies the distinction between the politics of affirmation and the politics of critique: Debord's politics of critique holds that the only legitimate act in the present is that of negation. As Debord makes clear, the revolutionary avant-garde must precede the artistic avant-garde. Only through the dialectics of negation will the contemporary state of "poverty" be replaced by a society of true "material and spiritual richness." In other words, the act of affirmation - of "waking up to the very life we are living," as Cage put is, can only come after the revolution, after the "sweeping and cleaning" proposed by Tzara. To Cage, critics like Debord are mistaken in their judgement that the present is entirely without richness. Against this view, the adherents of an affirmative politics insist that there does indeed exist - in the present - a foundation of richness. The problem, for individuals like Cage and Ono, is simply that this foundation is - at least at present - small, perhaps so small as to require a magnifying glass to identify it.

Reclaiming the term "affirmation" will require its redefinition, of course, as has been the case with similar terms. It need not imply a concomitant negation of what Marcuse called "the factual world" and its "daily struggle for existence." This, in fact, is the lesson of one of Cage's most shocking anecdotes. "I went to a concert upstairs in Town Hall," Cage recounted:

The composer whose works were being performed had provided program notes. One of these notes was to the effect that there is too much pain in the world. After the concert I was walking along with the composer and he was telling me how the performances had not been quite up to snuff. So I said, "Well, I enjoyed the music, but I didn't agree with that program note about there being too much pain in the world." He said, "What? Don't you think there's enough?" I said, "I think there's just the right amount." (Cage, Silence 93)

Cage's statement is easy to misinterpret as quiescent. It is not - at least not necessarily. It is perfectly consistent to say that the pain in the world that exists today is the right amount, but that it will not be the right amount tomorrow, and thus, that I must work to reduce it. This is to say that, against Debord, there is no requirement to dismantle before rebuilding. Indeed, the act of construction must begin at once. 


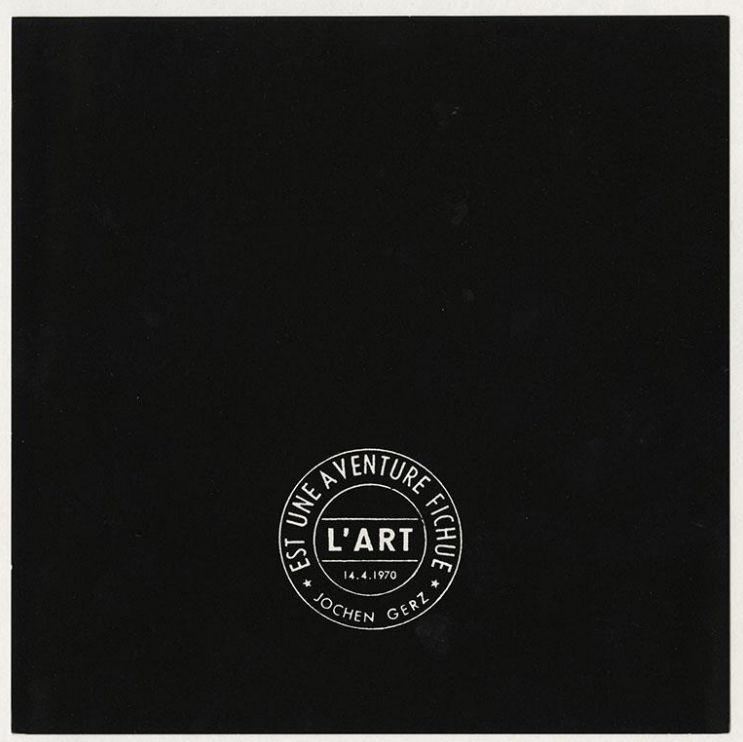

Figure 4: Joachim Gerz, "L'art est une aventure fichue." Postsachen. Fluxus West Collection, Special Collections, University of Iowa Libraries. (c) 2020 Artists Rights Society (ARS), New York / VG Bild-Kunst, Bonn.

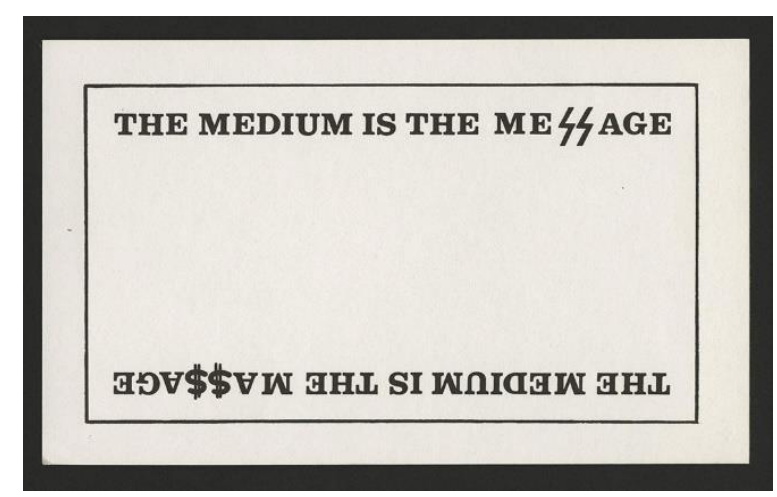

Figure 5: Joachim Gerz, "The Medium is the Message/Massage." Postsachen. Fluxus West Collection, Special Collections, University of Iowa Libraries. (C) 2020 Artists Rights Society (ARS), New York / VG Bild-Kunst, Bonn.

And this, to return to Postsachen, is what I see as the essential tension at play in the materials collected in Gerz's modest cardboard box. Some of the objects and texts speak the language of Debord's call for the "dépassement de l'art" at the service of the revolutionary avant-garde that the Situationists associated with the 
act of détournement. ${ }^{10}$ Works like "L'art est une aventure fichue" (Art is a useless (or broken) project) fall within this category, as does "The medium is the message/The medium is the massage," which takes the McLuhanite insight into decidedly Debordian territory even as performs the very assertion it makes (by replacing the "ss" in "message" with the symbol of the Nazi Schutzstaffel and the "ss" in "massage" with a pair of U.S. dollar signs (fig. 4; fig. 5). Perhaps the most explicitly Situationist is the manifesto-like statement (printed in French, German, and English) in which Gerz identifies "spectacle" as the contemporary condition most responsible for inhibiting direct communication (fig. 6).

LA NOTION DU SPECTACULAIRE SE SUBSTITUANT TOU.JOURS A L'INFORMATION, JE M'EFFORCE DE LIER AU PLUS PRES LA PERCEPTION D'UN PROCESSUS PROPOSE A CELUI-CI. LE PROCESSUS ETANT COMPOSE D'ELEMENTS DETERMINES ET NON-DETER MINES. IL IMPORTE DE NE LES ME LANGER DANS AUCUNE PHASE. C. -A.-D. LES MYSTIFIER. CELA S'APPLIQUE A LA PROPOSITION MEME, A SON EXECUTION FT A SA REPRESENTATION. LA SEULE QUALITE DU PROCESSUS ETANT SA NEUTRALITE.

JOCHEN (;ERZ

SINCE THE NOTION OF THE SPECTACULAR TENDS TO SUBSTITUTE ITSELF FOR INFORMATION, I TRY TO LINK THE PERCEPTION OF A PROPOSED PROCESS AS CLOSELY AS POSSIBLE TO THE PROCESS ITSELF. THIS BEING COMPOSED OF DETERMINED AND NON-DETERMINED ELEMENTS, IT IS IMPORTANT NOT TO MIX THE TWO, I. E. "MYSTIFY" THEM. THIS REFERS TO THE PROPOSITION ITSELF, TO ITS EXECUTION AND TO ITS REPRESENTATION. THE ONLY QUALITY OF THE PROCESS BEING ITS NEUTRALITY.

JOCHEN GERZ

DER BEGRIFF DES SPEKTAKULAEREN ERSETZT WEITGEHEND DIE INFORMATION ICH BEMUEHE MICH DAHER. DIE WAHRNEHMUNG EINES ZUR DURCHFUEHRUNG VORGESCHLAGENEN PROZESSES SO ENG ALS MOEGLICH AN DIESEN ZU BINDEN ES IST DAZU NOTWENDIG, EINE VERMISCHUNG, D. H. "MYSTIFIZIERUNG" DER BESTIMMTEN UND NICHT-BESTIMMTEN ELEMENTE, AUS DENEN DER PROZESS SICH ZUSAMMENSETZT. IN JEDER PHASE DESSELBEN ZU VERMEIDEN. DAS GILT FUER DIE PROPOSITION. IHRE DURCHFUEHRUNG UND IHRE REPRODUKTION. DIE EINZIG MOEGLICHE QUALITAET DES PROZESSES IST SEINE NEUTRALITAET.

JOCHEN GERZ

Figure 6: Joachim Gerz, "Since the notion of the spectacular. ..." Postsachen. Fluxus West Collection, Special Collections, University of Iowa Libraries. (C) 2020 Artists Rights Society (ARS), New York / VG Bild-Kunst, Bonn.

\footnotetext{
${ }^{10}$ Engagement with Situationist discourse and practice would remain crucial to Gerz's work for years after. Stephen Snoddy, in an essay on Gerz's large-scale photo and text works of 1988-92, draws an implicit connection with Debordian notions in the following way: "Gerz's laconic images undermine photography, and through his carefully considered text, he confuses the observer. The text intervenes and complicates the initial viewing, and the observers must mobilise their own thoughts again to refresh or to reinforce a first viewing or to invent a second interpretation" (67-68).
} 
SINCE THE NOTION OF THE SPECTACULAR TENDS TO SUBSTITUTE ITSELF FOR INFORMATION, I TRY TO LINK THE PERCEPTION OF A PROPOSED PROCESS AS CLOSELY AS POSSIBLE TO THE PROCESS ITSELF. THIS BEING COMPOSED OF DETERMINED AND NON-DETERMINED ELEMENTS, IT IS IMPORTANT NOT TO MIX THE TWO, I.E. “MYSTIFY” THEM. THIS REFERS TO THE PROPOSITION ITSELF, TO ITS EXECUTION AND TO ITS REPRESENTATION. THE ONLY QUALITY OF THE PROCESS BEING ITS NEUTRALITY.

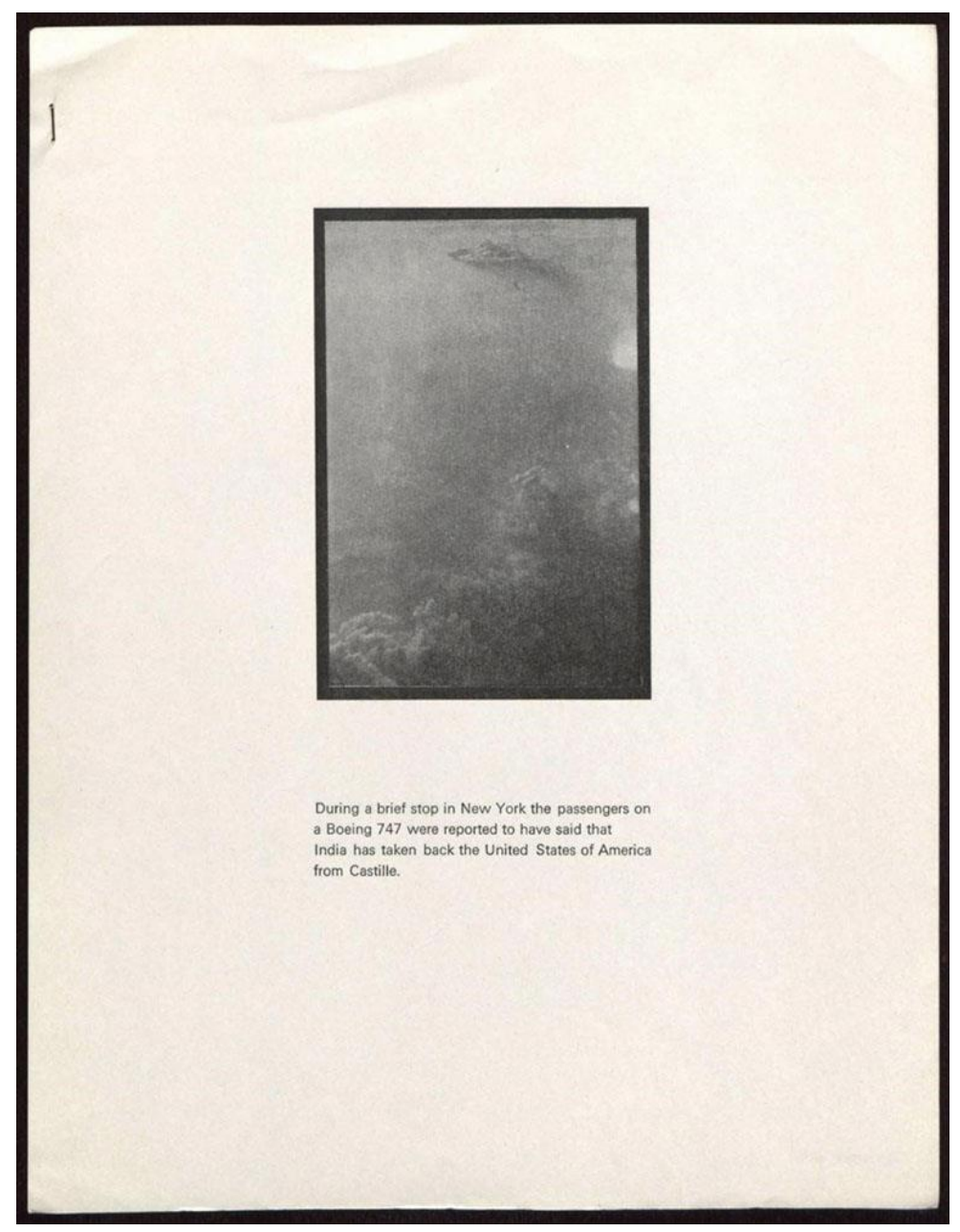

Figure 7: Joachim Gerz, "During a brief stop in New York...." Postsachen. Fluxus West Collection, Special Collections, University of Iowa Libraries. (C) 2020 Artists Rights Society (ARS), New York / VG Bild-Kunst, Bonn. 


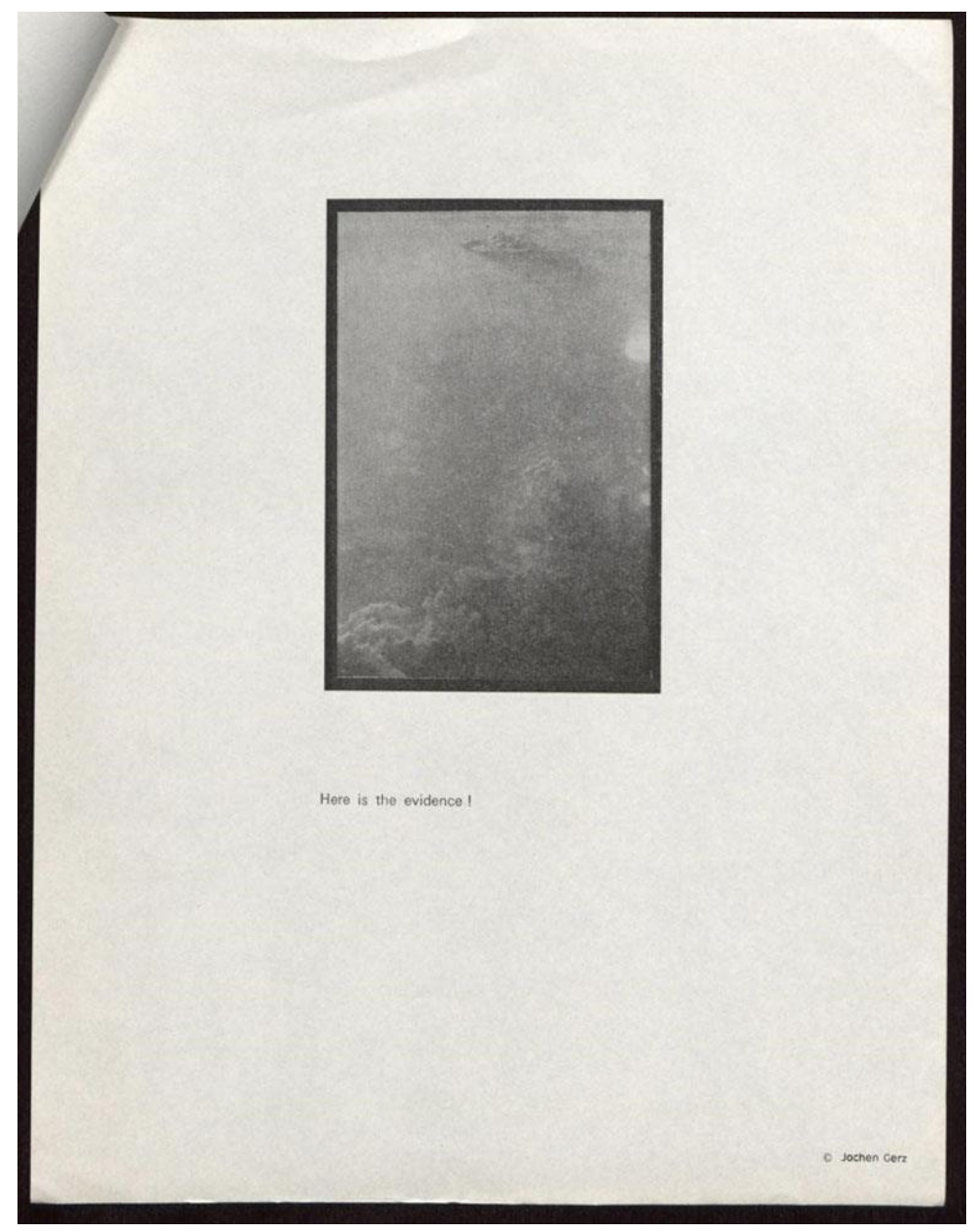

Figure 8: Joachim Gerz, "Here is the evidence!" Postsachen. Fluxus West Collection, Special Collections, University of Iowa Libraries. (c) 2020 Artists Rights Society (ARS), New York / VG Bild-Kunst, Bonn.

Nevertheless, what makes Postsachen distinctive is not that it extends the legacy of the SI, but that it does so while simultaneously setting it in relation to the very different imperative of Fluxus. Alongside its various Debordian works of aesthetic dépassement and political critique, Gerz's Postsachen contains works that articulate an explicitly affirmative dimension of the sort we have witnessed in Cage and Ono. Some are playful in the manner of Fluxus, like the modest illustrated story, comprised of two pages of standard-sized paper stapled together in the upper lefthand corner. On page one, we find a poorly printed photograph of clouds in the sky, beneath which one reads the following caption: "During a brief stop in New York the passengers on a Boeing 747 were reported to have said that India has 
taken back the United States of America from Castille [sic]." Flipping to page two, we find the very same photograph, this time with a different caption: "Here is the evidence!" (fig. 7; fig. 8). Rather than function as "educative propaganda," as Debord would wish, Gerz's puzzling conjunction of image and text elicits laughter rather than outrage, and with it, recalls the Zen-like riddles that were produced by George Brecht, Ken Friedman, and other Fluxus artists whom Maciunas later described as evidence of Fluxus's debt to vaudeville, children's games, gags, and Duchamp (Smith, Fluxus 181).

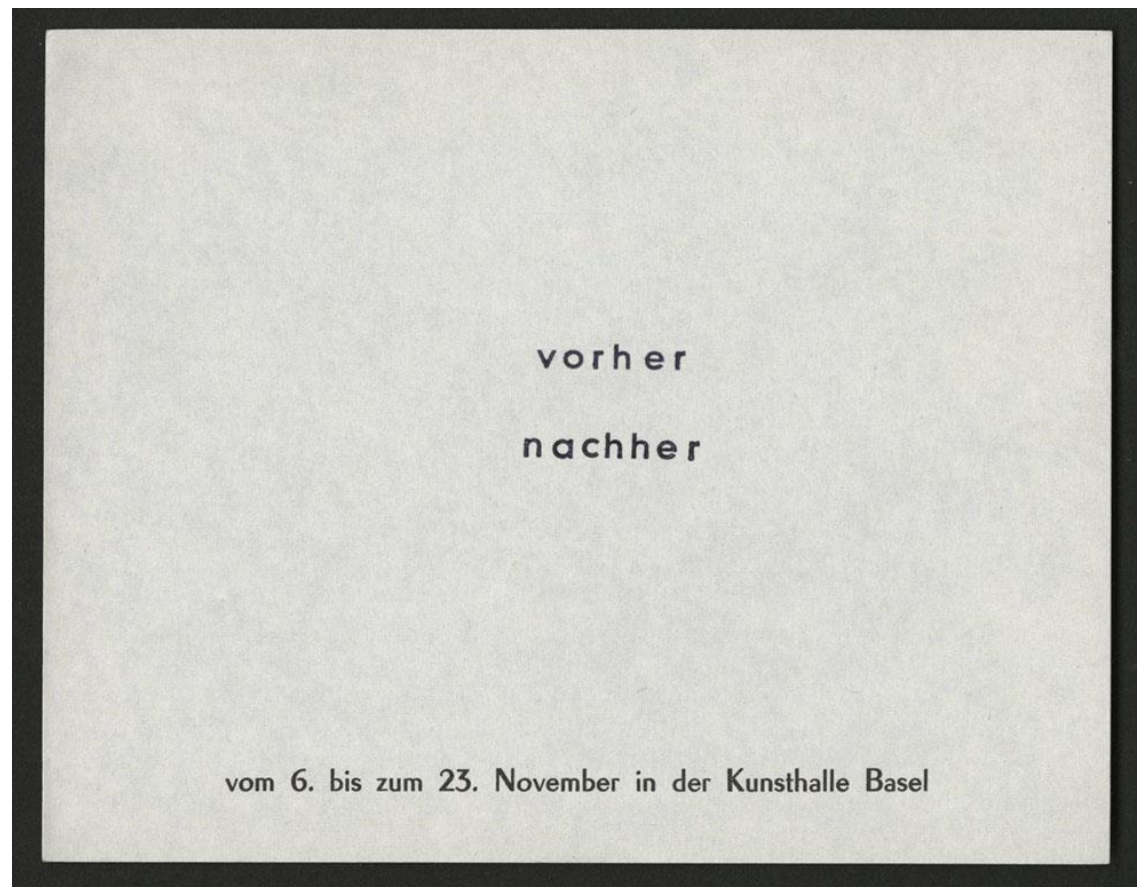

Figure 9: Joachim Gerz, "Vorher / nacher." Postsachen. Fluxus West Collection, Special Collections, University of Iowa Libraries. (C) 2020 Artists Rights Society (ARS), New York / VG Bild-Kunst, Bonn.

Similarly Zen-like is the poem "vorher; nachher" (before; after) (fig. 9). The text presents us with a puzzle, as it identifies the two temporalities absent in its experience - that is: the "now" that separates before from after. Perhaps the "now" is represented spatially as the small space between the two words, the otherwise absent present. If so, the reading of the poem functions as a performative rejection of Debord's claim that the poverty of the present demands its dépassement. Here, the reading of the poem fixes us in a momentary, yet unnamed, present, a present that is fleetingly brief, since the text contains but two words. Nevertheless, it is a 
present, and the reading of it serves to affirm as inescapable Marcuse's "factual world of daily struggle."

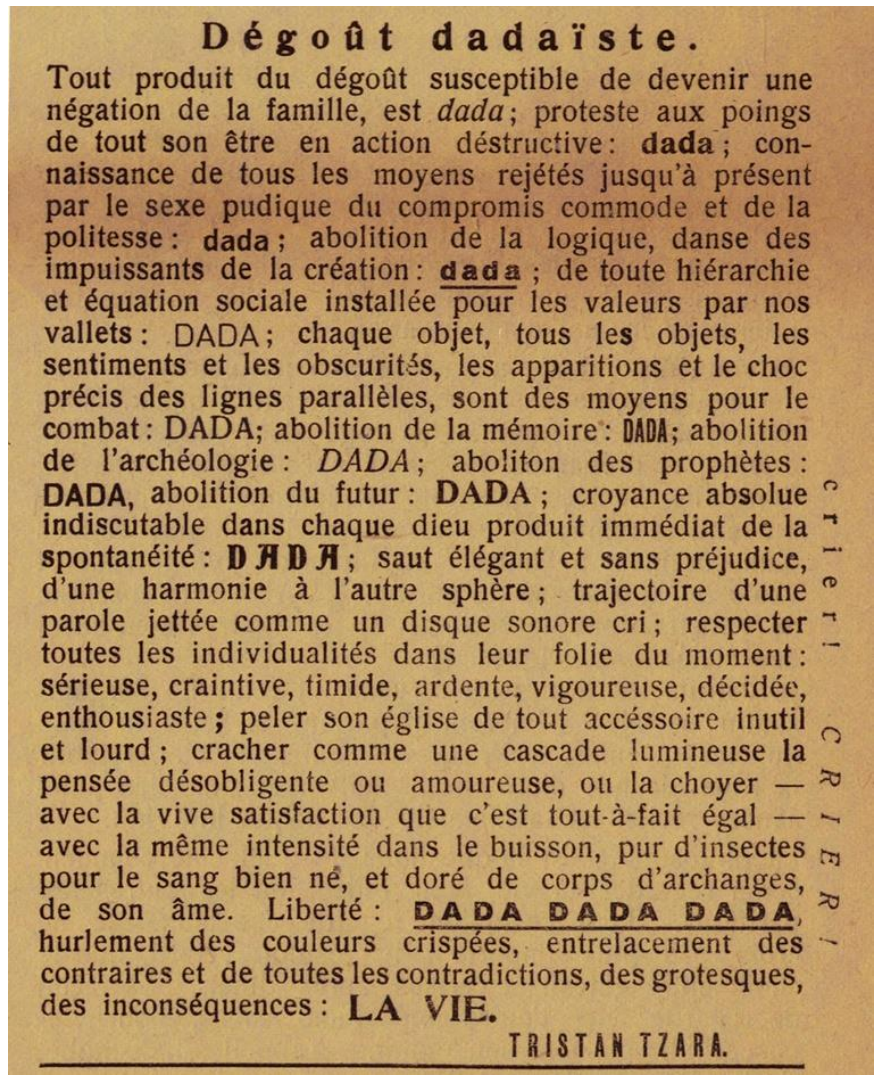

Figure 10: Tristan Tzara, Manifeste Dada 1918" (final section). Dada, no. 3 (Zurich, 1917). International Dada Archive, Special Collections, University of Iowa Libraries.

In other words, Gerz's Postsachen asks us to consider Dada's future - or futures - as torn between two fundamentally opposed visions of the avant-garde: on the one hand, an avant-garde of critique, as articulated by Debord and the Situationists, and on the other, an avant-garde of affirmation, as practiced by Cage and the artists of Fluxus. And were we to ask when, precisely, this internal division within the avant-garde first made its appearance, we should recall that although Tzara's 1918 Dada Manifesto insists that "every product of disgust ... is Dada," the final word of the manifesto is nevertheless unreservedly affirmative (Harrison and Wood, Art in Theory 257). In all caps, it cries out: "LA VIE” (fig. 10). 


\section{Works Cited}

Cage, John. Silence. Wesleyan UP, 1961.

Debord, Guy. “L'avant-garde de la présence." Internationale Situationniste, no. 8, Jan. 1963, pp. 14-22.

-. "The Avant-Garde of Presence." Situationist International Anthology, edited and translated by Ken Knabb, rev. and expanded edition, Bureau of Public Secrets, 2006, pp. 142-45.

. "Definitions." Translated by Ken Knabb, Situationist International Online. https://www.cddc.vt.edu/sionline///si/definitions.html. Accessed 25 July 2018.

. "Définitions." Internationale Situationniste, no. 1, June 1958, pp. 13-14.

. "The Situationists and the New Forms of Action in Politics and Art." Situationist International Anthology, edited and translated by Ken Knabb, rev. and expanded edition, Bureau of Public Secrets, 2006, pp. 402-07.

Debord, Guy, and Gil Wolman. "Mode d'emploi du détournement." Les lèvres nues, no. 8, May 1956, pp. 2-9.

—. "A User's Guide to Détournement." Situationist International Anthology, edited and translated by Ken Knabb, rev. and expanded edition, Bureau of Public Secrets, 2006, pp. 14-21.

Déotte, Jean-Louis. "Situation: Les paradoxes de la commande artistique - Jochen Gerz," Appareil, no. 20, 2018, pp. 1-6. https://doi.org/10.4000/appareil.2713.

Drathen, Doris von. "On the Realism of Poeisis." Jochen Gerz, Life After Humanism: Photo/Text 1988-1992, edited by Peter Friese, Edition Cantz, 1992, pp. 142-50.

Edition Hundertmark. http://www.hundertmark-gallery.com/editions.0.html.

Friedman, Ken. "Re: Jochen Gerz's 'Postsachen' in the Iowa Fluxus collection." E-mail message received by the author 31 Aug. 2017.

Frieling, Rudolf. The Art of Participation: 1950 to Now. San Francisco Museum of Modern Art, 2008.

Gerz, Jochen. "Creating a Cultural City." Third Text, vol. 21, no. 4, 2007, pp. 45762. https://doi.org/10.1080/09528820701433992

_. Postsachen (1968-1972). Edition Hundertmark, 1973.

. "Toward Public Authorship," Third Text, vol. 18, no. 6, 2004, pp. 649-56. https://doi.org/10.1080/0952882042000285050

Gerz, Jochen, and Simon Baker. "Jochen Gerz: Interviewed by Simon Baker, Paris, February 2001." Oxford Art Journal, vol. 24, no. 2, 2001, pp. 27-39. https://doi.org/10.1093/oxartj/24.2.25

Harrison, Charles, and Paul Wood, editors. Art in Theory 1900-2000: An Anthology of Changing Ideas. Blackwell, 2003.

Hohlfeldt, Marion. "Caution Art Corrupts: Reflections on the Meaning of Public Spaces in the Work of Jochen Gerz." Jochen Gerz - Res Publica: The Public Works 1968-1999. Hatje Cantz, 1999, pp. 9-15. 
Home, Stewart. The Assault on Culture: Utopian Currents from Lettrism to Class War. AK P, 1991.

Huyssen, Andreas, Twilight Memories: Marking Time in a Culture of Amnesia. Routledge, 1994.

Jappe, Anselm. "Sic Transit Gloria Artis: 'The End of Art' for Theodor Adorno and Guy Debord." SubStance, vol. 28, no. 3, pp. 102-28. https://doi.org/ $\underline{10.1353 / \text { sub.2006.0008 }}$

Kostelanetz, Richard. Conversing with Cage. Routledge, 2003. https://doi.org/ 10.4324/9780203427033

Liberti, Giuseppe di. "Fait/événement - document/monument: La temporalité à l'œuvre." Images Re-vues, no. 11, 2013. https://journals.openedition.org/ imagesrevues/3319.

Maciunas, George. Fluxus Manifesto. [circa. 1963]. Archive Sohm, Staatsgalerie, Stuttgart.

Marcuse, Herbert. Negations: Essays in Critical Theory. Beacon P, 1968.

Smith, Owen. "Developing a Fluxable Forum: Early Performance and Publishing." The Fluxus Reader, edited by Ken Friedman, Academy Editions, 1998, pp. 3-21.

- Fluxus: The History of an Attitude. San Diego State UP, 1998.

Snoddy, Steven. "May 25, 1991. .. ." Jochen Gerz, Life After Humanism: Photo/Text 1988-1992, edited by Peter Friese, Cantz, 1992, pp. 67-68.

Stubblefield, Thomas. "Do Disappearing Monuments Simply Disappear?: The Counter-Monument in Revision." Future Anterior, vol. 8, no. 2, Winter 2011, pp. 1-11. https://doi.org/10.1353/fta.2011.0015

Tzara, Tristan. “Dada Manifesto 1918." Translated by Ralph Manheim. The Dada Reader: A Critical Anthology, edited by Dawn Ades, Tate, 2006, pp. 36-42.

Vickery, Jonathan. "Art, Public Authorship and the Possibility of ReDemocratization." Visual Culture in Britain, vol. 12, no. 2, 2011, pp. 219-35. https://doi.org/10.1080/14714787.2011.575296

Vowickel, Andreas. "Absence of the Presence: Concerning the Idea of Production in the Work of Jochen Gerz." Jochen Gerz, Life After Humanism: Photo/Text 1988-1992, edited by Peter Friese, Edition Cantz, 1992, pp. 39-44.

Young, James. "The Counter-Monument: Memory against Itself in Germany Today." Critical Inquiry, vol. 18, no. 2, Winter 1992, pp. 267-96. https://doi.org/ $\underline{10.1086 / 448632}$

. The Texture of Memory: Holocaust Memorials and Meaning. Yale UP, 1993.

Copyright (C) 2020 Roger Rothman 